ПРОФЕСІЙНА ГОТОВНІСТЬ МАЙБУТНІХ ФАХІВЦІВ

СОЦІОНОМІЧНИХ ПРОФЕСІЙ ДО ВПРОВАДЖЕННЯ

ІНКЛЮЗИВНОЇ ОСВІТИ: АКСІОЛОГІЧНІ ЗАСАДИ

\title{
PROFESSIONAL PREPAREDNESS OF FUTURE SPECIALISTS OF SOCIONOMIC PROFESSIONS FOR THE INTRODUCTION OF INCLUSIVE EDUCATION: AXIOLOGICAL PRINCIPLES
}

у статті актуалізовано важливість профресійної підготовки майбутніх фрахівців сочіономічних просресій до роботи з особами з особливими потребами. Дослідження даної проблеми унеобхіднило аксіологічне осмислення готовності студентів вищо школи до даного виду діяльності. Проаналізовано результати досліджень вітчизняних та закордонних науковців, які дали змогу стверджувати, що інклюзивне навчання в закладах освіти є дієвим за умов есективної готовності фрахівців до роботи з особами 3 особливими потребами, позитивного ставлення всього колективу та самих фрахівців до таких осіб, налагодження партнерських взаємин із батьками та командного підходу до вирішення інклюзивних проблемних завдань. Обгрунтовано, що формування цінностей інклюзивної культури в освітній організації та в суспільстві загалом є довготривалим процесом. Охарактеризовано можливість включення осіб з особливими потребами в освітні заклади, які передбачають спеціальну корекційну допомогу і психолого-педагогічну підтримку з боку фрахівиів. Наголошено на важливому завданні, яке нині ставиться перед закладами вищої освіти, підготовиі майбутніх фрахівців сочіономічних профресій до професійної інклюзивної діяльності на аксіологічних засадах. З'ясовано що вища школа сприяє фрормуванню особистісного сенсу, власної ціннісної мотивації, необхідних для роботи з дітьми з особливими потребами. Ефективне забезпечення своєрідної корекційної допомоги, соціальної та психолого-педагогічної підтримки супроводу осіб з обмеженими можливостями в освітнє середовище передбачає вирішення необхідних загальних і специфрічних завдань професійної діяльності. На аксіологічних засадах дієво окреслено специорічні напрями роботи майбутніх фрахівців соціономічних професій в інклюзивному оточенні. Зроблено висновок, що на готовність фрахівців соціономічних професій до впровадження освітніх інклюзій впливають аксіологічні засади професійної підготовки в закладах вищої освіти, які звернені до глибинних основ продуктивної міжособистісної взаємодії, переосмислення наявних стереотипів і подолання внутрішньоособистісних страхів і бар'єрів як у майбутніх фрахівців, так і в осіб з особливими потребами.

Ключові слова: майбутні фрахівці соціономічних професій, інклюзивна освіта, особи з особливими потребами, аксіологічні засади профресійної підготовки.

The importance of professional training of future specialists of socionomic professions to work with people with special needs are highlighted in the article. The study of this problem required axiological understanding of the readiness of high school students for this type of activity. The results of researches of domestic and foreign scientists, which allowed to state that inclusive education in educational institutions is effective under the conditions of effective readiness of specialists to work with people with special needs, positive attitude of the whole team and specialists to such people, establishing partnerships with parents and a team approach to solving inclusive problem tasks, are analyzed. It is substantiated that the formation of values of inclusive culture in the educational organization and in society as a whole is a long-term process. The possibility of including people with special needs in educational institutions, which provide special correctional assistance and psychological-pedagogical support from specialists, is characterized. Emphasis is placed on the important task currently facing institutions of higher education, that is the preparation of future professionals in socionomic professions for professional inclusive activities on an axiological basis. It was found that higher education contributes to the formation of personal meaning, self-worth motivation needed to work with children with special needs. Effective provision of a kind of correctional care, social and psychological-pedagogical support and support of people with disabilities in the educational environment involves solving the necessary general and specific tasks of professional activity. Specific areas of work of future specialists of socionomic professions in an inclusive environment are effectively outlined on the axiological basis. It is concluded that the readiness of specialists of socionomic professions to implementation of educational inclusions is influenced by axiological principles of professional training in institutions of higher education, which are addressed to the deep foundations of productive interpersonal interaction, rethinking existing stereotypes and overcoming interpersonal fears and barriers as by specialists, as by people with special needs. Key words: future specialists of socionomic professions, inclusive education, people with special needs, axiological principles of professional training.
Постановка проблеми в загальному вигляді. Нині інклюзивні практики актуалізували проблеми профресійної підготовки вчителів, психологів, соціальних працівників та фрахівців інших соціономічних професій до роботи 3 дітьми з особливими потребами. Набуття студентами у закладах вищої освіти (далі - ЗВО) необхідних для реалі- зації інклюзії особистісно-профресійних якостей та компетенцій, які б дозволяли успішно вирішувати практико-зорієнтовані завдання в даному напрямі фрахової діяльності, викликають у них труднощі як професійного, так і психологічного характеру. Це позначається на власній самооцінці та неготовності до діяльного фрункціонування з дітьми, яким 
властиві інклюзії. Тому на сучасному етапі дослідження даної проблеми виникає необхідність аксіологічного осмислення професійної готовності фрахівців до даного виду діяльності, що сповна б сприяло пошуку результативних організаційно-технологічних діяльнісних характеристик та віднаходженню шляхів побудови оптимальних паритетних взаємин між усіма учасниками освітньої взаємодії.

Аналіз останніх досліджень і публікацій. Проведений аналіз результатів наукових доробків вітчизняних і закордонних учених (В. Бондар, І. Гевко, Є. Клопота, А. Колупаєва, В. Ляшенко, Ю. Найда, О. Савченко, Н. Софрій, О. Фурман, Є. Кутепова, О. Кузьмна, Л. Ткаченко, В. Хитрюк, J. Ilan, A. Boer, L. Florian, H. Linklater, J. SagnerTapia, S. Shlessinger, R. Slee, K. Sutton та ін.) дозволяє говорити про низький рівень особистісної та профресійної готовності педагогів до роботи в умовах інклюзивної освіти. Науковець Л. Ткаченко зазначає, що інклюзивне навчання в загальноосвітніх закладах віддзеркалює одну із провідних демократичних ідей - «усі діти є цінними й активними членами суспільства», тому головне призначення інклюзії полягає в розкритті здібностей кожного вихованця за допомогою освітньої програми [8, с. 129]. Важливою слугує думка І. Гевко про те, що в освітньому процесі вищої школи потрібно здійснити перегляд змістового наповнення спеціальних навчальних дисциплін, загалом змінити підходи до використання методів підготовки фрахівців до роботи в інклюзивних умовах. Такі заходи сприяють реалізації освітньої парадигми, що спрямована на пізнання і врахування особистісних потреб особливих учнів відповідно до їхнього віку, специфрічного індивідуального характеру, ступеня фрізичного та психічного порушення, власних психологічних якостей особистості тощо [2, с. 56-57]. Інклюзивну освіту як альтернативну педагогіку розглядають L. Florian, H. Linklater, які наголошують на тому, що вона заснована не стільки на виділенні особливих потреб окремих учнів (констатація їхніх слабких потенцій та здібностей), скільки на гнучкій мисленнєвій діяльності педагога для вмілого реагування на різноманітність здатностей учнів, підтримування їх в інтегрованих групах [9]. Водночас всі науковці сходяться в тому, що запровадження в навчальному процесі технологій інклюзивної освіти вимагає підготовки всього учнівського колективу, позитивного ставлення самого вчителя до дитини, налагодження партнерських стосунків із батьками та командного підходу до вирішення інклюзивних питань.

Виділення не вирішених раніше частин загальної проблеми. Суттєвою проблемою освоєння інклюзивних практик $€$ особистісна неготовність фахівців соціономічних професій до результативного їх запровадження в навчальному процесі вихованців. Особистісне обґрунтування інклю- зивних практик тісно пов'язане 3 думками про ставлення до людей з інвалідністю та їхню значущість для соціуму. Тому якісно нові засади-характеристики інклюзивного освітнього середовища зумовили необхідність введення в педагогічний дискурс інклюзивної готовності як важливого компонента професійної компетентності майбутнього фахівця, що означає його соціальну позицію та гуманістичну спрямованість. Отже, актуалізується проблема готовності майбутніх фрахівців до діяльності в інклюзивну освітньому середовищі, а саме ії аксіологічний компонент.

Мета статті полягає в розкритті аксіологічних засад профресійної готовності фахівців соціономічних профресій до інклюзивного навчання.

Виклад основного матеріалу. Формування цінностей інклюзивної культури в освітній організації та в суспільстві загалом є тривалим процесом. У Саламанкській декларації (1994р.) докладно визначено поняття «особливі потреби» та «діти 3 особливими потребами», що стосується чималої кількості дітей і молодих людей, у яких є різні фрізичні чи розумові утруднення в навчанні. Інакше ці потреби трактуються як «спеціальні освітні потреби на певних етапах навчання у школі» [7]. Великий вплив на становлення інклюзивної освіти мають міжнародні організації (ЮНЕСКО, Організація з безпеки та співробітництва в Європі тощо), Конвенції Організації Об'єднаних Націй «Про права дитини» та ін., які як пріоритетний розвиток системи освіти рекомендують інклюзивну освіту, спрямовану на реалізацію прав громадян, здобуття якісної освіти та соціальну інтеграцію.

Визнання Україною міжнародних стандартів щодо інклюзивної освіти [1] посилило увагу громадянського суспільства до проблем дітей, які мають ті чи інші відхилення в розвитку, та зумовило необхідність розробки цілеспрямованих дій державних органів влади щодо створення найсприятливіших соціальних і психолого-педагогічних умов для забезпечення їхньої самоактуалізації, життєвого і професійного самовизначення, активної участі в системі сучасних суспільних взаємин. Тому інклюзивна освіта з повним правом нині $€$ одним із пріоритетних напрямів державної освітньої політики України [5]. Сучасна парадигма освіти виходить з ідеї створення сприятливих умов для осіб із різними потребами як в навчанні, так і у вихованні.

Можливість включення дітей 3 особливими потребами в освітні заклади передбачає спеціальну корекційну допомогу і психолого-педагогічну підтримку, завданнями яких $€$ інспектування їхнбого розвитку, навчальної успішності, вирішенням проблем соціальної адаптації тощо [4]. Це спричинює підтримку високого рівня викладання, пошук викладачем власної манери поведінки в навчальній аудиторії, високого профресіоналізму й індивідуального підходу до кожного вихованця. 
Важливо, що для педагогічної спільноти ціннісне ставлення до дітей із нетиповим розвитком виступає життєво-професійним завданням, оскільки нині недостатньо констатувати неготовність включення дітей з особливостями розвитку в масові освітні організації, зміну базових принципів навчання, а потрібно допомогти педагогу виробити власні смисли даної практики. Тому вагомим завданням, яке ставиться перед закладами вищої освіти, є підготовка на аксіологічних засадах майбутніх фахівців соціономічних професій до професійної інклюзивної діяльності. Саме у вищій школі кожен майбутній фахівець повинен визначити особистісний сенс, ціннісну особистісну мотивацію необхідну для роботи з такими дітьми [3; 6]. Формування у студента цінностей інклюзивної культури - це тривалий процес (від першого до останнього років навчання у ЗВО), пов'язаний із переживанням набутого практичного досвіду. Цінності і смисли породжуються особистістю за допомогою духовно-душевних переживань, докладених внутрішніх зусиль, ситуативним переосмислення тощо. Не випадково ініціаторами включення особливих дітей в освітні практики є педагоги, психологи, соціальні працівники тощо, професійне життя яких пов'язано із проблемами осіб з інвалідністю (діти, родичі, близькі). Ця практика безпосередньо зумовлена гуманістичними основами, які слугують цінністю для студентів. Крім того, досить важливо у процесі підготовки фрахівців формувати в них позитивне ставлення до інклюзивної освіти. Тому ефрективним напрямом системної підготовки $€$ включення та зреалізування відповідних спеціальних тем під час вивчення традиційних навчальних дисциплін, що дозволяє актуалізувати та продукувати інклюзивну компетентність.

Підвищення рівня психолого-педагогічної підготовки фрахівців, які працюють із дітьми з особливими потребами в умовах загальної освіти, уможливлюється як в межах психолого-педагогічного напряму (бакалавр - магістр), так і через навчання бакалаврів-фрахівців (учителі, методисти, учителідефектологи, учителі-логопеди, соціальні працівники, психологи тощо) у магістратурі за напрямом підготовки «011. Освітні, педагогічні науки» (освітньо-профресійна програма «Інклюзивна освіта, корекційна педагогіка»). У підготовці майбутніх фахівців у вищій школі варто враховувати те, що інклюзивна освіта спрямована не на ліквідацію сорормованої системи спеціальної (корекційна) освіти, а на взаємопроникнення івзаємооб'єднання систем загальної та спеціальної освіти, оскільки провідною під час створення системи інклюзивної освіти $€$ наявність тих студентів, які готові до змін соціальних і особистісно-психологічних.

Майбутні фрахівці інклюзивної освіти повинні навчитися еоективно забезпечувати педагогічний супровід дітей з обмеженими можливостями в освітнє середовище, вирішувати як загальні завдання професійної діяльності, так і специфічні, що передбачають такі напрями майбутньої роботи:

- проведення діагностики для визначення типу психічного відхилення в осіб з інклюзіями;

- здійснення психологічного обстеження дітей різного віку з мовними і руховими порушеннями із використанням рекомендованого інструментарію, включаючи первинну обробку отриманих результатів і вміння складати психологічний висновок;

- прогнозування динаміки змін стану і розвитку дитини залежно від використовуваних педагогами впливів;

- ведення психотерапевтичної роботи з дорослими учасниками інклюзивного освітнього процесу, зокрема і з батьками дитини з обмеженими можливостями;

- фрормування толерантних взаємин в інклюзивну шкільному колективі та в колективі вчителів як дорослих учасників інклюзивного освітнього процесу;

- проєктування і розробку корекційно-розвивальних програм роботи з дітьми шкільного віку;

- визначення потреб конкретної дитини за певною освітньою програмою та ін.

Обов'язкове опанування майбутніми фахівцями у ЗВО професійно-аксіологічних компонентів компетентностей у сорері психолого-педагогічного супроводу дітей з обмеженими можливостями результативно впливає на прийняття теорії та методології інклюзивної освіти, організацію спільної та індивідуальної діяльності дітей із різними типами порушень у розвитку; уміння співвідносити освітні завдання і завдання соціальної адаптації, а також сприяє вмілому використанню рекомендованих методів та освітніх технологій, що дозволяють ефективно вирішувати діагностичні і корекційно-розвивальні завдання; збиранню і підготовці документації про особливості дитини для обговорення її проблем на психолого-медико-педагогічному консиліумі освітньої установи тощо.

Підсумовуючи вищевикладене, зазначимо, що ефрективне зреалізування інклюзивної освіти на аксіологічних засадах безпосередньо залежить від спеціальної психолого-педагогічної підготовки майбутніх фрахівців соціономічних професій у вищій школі.

Висновки. Основна мета зреалізування спеціальних навчальних програм, що забезпечують фрормування готовності майбутніх фрахівців до діяльності в освітніх інклюзивних умовах, передбачає побудову чітких уявлень про фрілософрькі, методологічні засади і принципи інклюзивної освіти, висвітлення проблеми нормативно-правового забезпечення інклюзивної освіти, практикування сучасних моделей психолого-педагогічного супроводу дітей зособливими освітніми потребами, фрормування профресійно-аксіологічних компетен- 
цій в організації інклюзивної практики. У процесі підготовки фрахівців початкових класів до інклюзивної освіти аксіологічні засади мають первинне, фундаментальне значення, оскільки звернені до глибинних основ продуктивної міжособистісної взаємодії. Пояснюючи природу індивідуальних смислів, аксіологія відкриває значущість ціннісного переживання педагогом і дитиною один одного, важливість переосмислення наявних стереотипів, внутрішньоособистісних страхів та бар'єрів.

\section{БІБЛІОГРАФІЧНИЙ СПИСОК:}

1. Адаптована конвенція ООН щодо осіб 3 особливими потребами. Нью-Йорк, 13 грудня 2006 p. URL: www.osmhi.org/index.php?page=200\& news $=401 \&$ pages.

2. Гевко І. Інклюзивна освіта в Україні: сучасний стан та проблеми розвитку. Науковий вісник Миколаївського національного університету імені B.О. Сухомлинського. Серія «Педагогічні науки». 2019. № 1 (64). С. 52-58.

3. Главацька О. Л. Самоменеджмент як засіб підвищення творчого потенціалу соціального працівника. Соціальна робота: виклики сьогодення : збірник наукових праць V Всеукраїнської науково-практичної конференції, м. Тернопіль, 26-27 квітня 2018 р. Тернопіль : ТНПУ імені В. Гнатюка, 2018. С. 25-28.
4. Колупаєва А., Сосрій Н., Найда Ю. Інклюзивна школа: особливості організації та управління : навчально-методичний посібник. Київ, 2010. 128 с.

5. Про внесення змін до Закону України «Про освіту» щодо особливостей доступу осіб з особливими освітніми потребами до освітніх послуг : Закон України від 23 травня 2017 р. № 2053-VIII. URL: https://zakon2.rada.gov.ua/laws/ show/2053-viii.

6. Ребуха Л. Інноваційно-технологічні процеси у фундаменталізації професійної підготовки майбутніх соціальних працівників. Інноваційна педагогіка. 2018. Вип. 3. С. 164-167.

7. Саламанська декларація та рамки дій щодо освіти осіб з особливими потребами, прийнята Всесвітньою конференцією щодо освіти осіб з особливими освітніми потребами: доступ і якість, 7-10 червня. Іспанія. 1994. URL : https://zakon.rada.gov.ua/laws/ show/995 001-94.

8. Ткаченко Л. Актуальні проблеми запровадження інклюзивної освіти в Україні. Сучасна українська освіта: стратегії та технології навчання молоді і дорослих : збірник наукових праць V Міжнародної науково-практичної інтернет-конференції, 27 лютого 2018 р. Переяслав-Хмельницький. 2018. C. 128-132.

9. Florian L., Linklater $\mathrm{H}$. Preparing teachers for inclusive education: using inclusive pedagogy to enhance teaching and learning for all. Cambridge Journal of Education. 2010. Vol. 40. Iss. 4. P. 369-386. 